\title{
Kualitas Fisik Kompos Feses Sapi Potong dan Kulit Kopi dengan Penambahan Aktivator Mol Bongkol Pisang dan EM4
}

\section{Physical Quality of the Compost in A Mixture of Beef and Coffee Pulp with the Addition of Activator Results Composting Mol Banana Weevil and EM4}

\author{
T. Karyono* dan J. Laksono \\ Fakultas Pertanian Prodi Peternakan, Universitas Musi Rawas \\ Jl. Sultan Mahmud Badarrudin II, Kel. Air kuti I, Lubuklinggau 31628 \\ *E-mail: teguhkaryono89@yahoo.co.id
}

(Diterima: 21 Maret 2019; Disetujui: 02 Mei 2019)

\begin{abstract}
ABSTRAK
Penelitian ini bertujuan untuk mengetahui kualitas fisik kompos dalam campuran feses sapi potong dan kulit kopi hasil pengomposan dengan penambahan aktivator MOL bongkol pisang dan EM 4 serta komposisi yang terbaik dari aktivator MOL bonggol pisang dan EM4 hasil pengomposan. Metode penelitian yang digunakan adalah Rancangan Acak lengkap (RAL) yang terdiri dari 6 perlakuan dan 4 ulangaan, yaitu A1 $=25 \mathrm{ml} \mathrm{MOL} / 5 \mathrm{~kg}$ bahan kompos (feses + kulit kopi), A2 $=30 \mathrm{ml} \mathrm{MOL} / 5 \mathrm{~kg}$ bahan kompos (feses + kulit kopi), A3 $=35 \mathrm{ml}$ MOL $/ 5 \mathrm{~kg}$ bahan kompos (feses + kulit kopi), A4 = $25 \mathrm{ml}$ EM4 / $5 \mathrm{~kg}$ bahan kompos (feses + kulit kopi), A5 $=30 \mathrm{ml} \mathrm{EM} 4 / 5 \mathrm{~kg}$ bahan kompos (feses + kulit kopi), A6 $=35 \mathrm{ml}$ EM4 $/ 5 \mathrm{~kg}$ bahan kompos (feses + kulit kopi). Karakteristik fisik dari kompos yang terdiri dari suhu, $\mathrm{pH}, \mathrm{bau} / \mathrm{aroma}$, warna dan tekstur diteliti dalam penelitian ini dan untuk mengetahui pengaruh perlakuan, data yang diperoleh dianalisis dengan analisa sidik ragam dan uji lanjut BNJ. Hasil penelitian pengaruh penambahan aktivator dalam campuran feses sapi potong dan kulit kopi terhadap kualitas fisik kompos, menunjukkan berpengaruh tidak nyata $(\mathrm{P}>0,05)$ terhadap suhu, $\mathrm{pH}$, bau/aroma dan warna serta berpengaruh nyata $(\mathrm{P}<0,05)$ terhadap tekstur kompos. Dapat disimpulkan bahwa penambahan aktivator MOL bongkol pisang dan EM4 pada bahan kompos feses sapi potong dan kulit kopi memberikan hasil tekstur yang terbaik pada perlakuan A6 $(2,13)$ dan memberikan hasil yang sama baik terhadap sifat fisik: suhu, $\mathrm{pH}$, bau/aroma, warna kompos.
\end{abstract}

Kata kunci: aktivator, feses sapi potong, kompos, kulit kopi

\section{ABSTRACT}

The objectives of this study are to determine the physical quality of the compost in a mixture of beef and coffee pulp with the addition of activator results composting MOL banana weevil and EM 4 as well as the composition of the best from MOL activator banana weevil and EM4 results composting. The method used was completely randomized design (CRD), which consists of 6 treatments and 4 replicates, namely: $A 1=25 \mathrm{ml} \mathrm{MOL} / 5 \mathrm{~kg}$ of compost material (Feces + Coffee pulp), A2 $=30 \mathrm{ml} \mathrm{MOL} / 5 \mathrm{~kg}$ of compost materials (Feces + Coffee pulp), A3 $=35 \mathrm{ml} \mathrm{MOL} / 5 \mathrm{~kg}$ of compost material (Feces + Coffee pulp), $A 4=$ $25 \mathrm{ml} \mathrm{EM4} \mathrm{/} 5 \mathrm{~kg}$ of compost material (Feces + Coffee pulp), A5 = 30 ml EM4 $/ 5 \mathrm{~kg}$ of compost material (Feces + Coffee pulp), A6 = $35 \mathrm{ml}$ EM4 $/ 5 \mathrm{~kg}$ of compost material (Feces + Coffee pulp). The physical characteristics of compost consisting of temperature, $\mathrm{pH}$, odor/aroma, color and texture examined in this study and to determine the effect of treatment, the data obtained were analyzed by analysis of variance and a further test HSD. With the effects of the addition of the activator in a mixture of beef and coffee pulp on the quality of the compost, showed no effect $(P>0.05)$ on the temperature, $p H$, odor/aroma and color as well as a significant effect $(P<0,05)$ on the texture of compost. It can be concluded that the addition of bioactivator MOL hump and EM4 the compost material feces of beef cattle and coffee skin results in the texture of the best in treatment $A 6(2,13)$ and give equally good results on the physical properties: temperature, $p H$, odor/aroma, color compos. 
Keywords: activators, beef cattle feces, coffee pulp, compost

\section{PENDAHULUAN}

Feses sapi potong merupakan limbah usaha peternakan yang dihasilkan dari sisa metabolisme ternak sapi yang sudah tidak dipergunakan lagi. Feses sapi potong mengandung cukup air dan memiliki $\mathrm{C}: \mathrm{N}$ rendah. Feses sapi potong dapat digunakan sebagai bahan dasar pembuatan kompos. Potensi limbah kotoran sapi (feses, urin dan sisa pakan) dapat dilihat dari jumlah populasi sapi disuatu wilayah. Berdasarkan hasil pendataan sapi potong yang dilaksanakan serentak di seluruh Indonesia mulai 1-30 Juni 2011, populasi sapi potong mencapai 14,8 juta ekor (Biro Pusat Statistik, 2011). Apabila satu ekor sapi rata-rata setiap hari menghasilkan 12 kilogram kotoran, maka kotoran sapi yang dihasilkan di Indonesia sebesar 177,6 juta kilogram perhari. Keadan potensial inilah yang menjadi alasan perlu adanya penanganan yang benar pada kotoran ternak. Yuli et al. (2010) menyatakan kandungan unsur hara feses sapi terdiri dari kandungan nitrogen $(\mathrm{N})$ 0,3-0,4 \%, phospor (P) 0,1-0,2\%, kalium (K) $0,10-0,15 \%$ dan air $80-85 \%$ serta $\mathrm{C} / \mathrm{N}$ ratio berkisar $19-25$. Perbandingan $\mathrm{C}$ dan $\mathrm{N}$ yang ideal dalam proses pengomposan dengan rasio terbaik adalah 30:1 (Isroi, 2009). Oleh karena itu diperlukan sumber karbon untuk mencapai nisbah $\mathrm{C} / \mathrm{N}$ yang ideal. Salah satu alternatif bahan yang ditambahkan adalah kulit kopi.

Sebagai produk samping dari usaha industri kopi, kulit kopi berpotensi untuk digunakan sebagai sumber bahan organik tanah dengan syarat telah dikomposkan terlebih dahulu. Hal ini mengingat bahwa nisbah $\mathrm{C} / \mathrm{N}$ pulpa kulit kopi sekitar 40, sedangkan untuk kulit tanduk kopi sekitar 140 yang merupakan angka yang sangat tinggi bila dibandingkan dengan nisbah $\mathrm{C} / \mathrm{N}$ yang tanah berkisar 10 - 20 (Baon et al., 2005). Pada tahun 2000 produksi kopi di Indonesia mencapai 554.574 ton dan pada tahun 2012 jumlah produksi kopi menjadi 748.109 ton. Diprovinsi Sumatera
Selatan luas area perkebunan kopi rakyat pada tahun 2013 sebesar 249.418 hektar dengan produksi 139.789 ton (Disbun Sum-Sel 2013 dalam BPS Sum-Sel dalam angka 2014). Dari data diatas maka potensi ketersediaan limbah kulit kopi cukup besar. Rasio kandungan kulit kopi dan biji kopi adalah 48 : 52. Dari $48 \%$ kandungan kulit kopi, $42 \%$ berupa kulit buah dan $6 \%$ kulit biji (kulit tanduk). Dari data diatas maka potensi ketersediaan limbah kulit kopi cukup besar.

Aktivator adalah zat penyebab aksi enzim (Rifai, 2004). Didalam aktivator terdapat mikroorganisme (jasad renik) yang berfungsi meningkatkan proses dekomposisi bahan organik yang bekerja memalui proses perubahan fisik dan kimia suatu bahan organik menjadi produk yang berbeda sifatnya (Sukanto, 2013 dalam Farida et al., 2013). Diketahui ada dua macam aktivator yaitu aktivator organik dan anorganik, aktivator organik adalah bahan-bahan yang mengandung $\mathrm{N}$ tinggi dalam bentuk bervariasi seperti protein dan asam amino. Beberapa contoh aktivator organik yaitu fungi dan tanah yang kaya akan humus sedangkan aktivator anorganik antara lain amonium sulfat, urea, amoniak, dan natrium nitrat.

Untuk meningkatkan unsur hara dan mempercepat hasil pengomposan pada proses pengomposan maka diperlukan penambahan aktivator seperti MOL bongkol pisang dan EM4. MOL Bongkol pisang dapat digunakan sebagai sumber mikroorganisme pengurai bahan organik atau dekomposer dalam pengomposan. Menurut Suhastyo (2011) dalam Moses (2013) adapun Jenis mikrobia yang telah diidentifikasi pada MOL bongkol pisang antara lain Azospirillium, Azotobacter, Bacillus, Aeromonas, Aspergillus, mikroba pelarut phospat dan mikroba selulotik. Mikrobia inilah yang biasa menguraikan bahan organik. Effective Microorganisme 4 (EM4) telah lama ditemukan, diteliti dan diseleksi terus menerus oleh seorang ahli pertanian 
bernama Profesor Teruo Higa dari Universitas Ryukyu, Jepang. EM4 terdiri dari kultur campuran dari beberapa mikroorganisme yang menguntungkan bagi pertumbuhan tanaman. Effective microorganisms (EM) mengandung spesies terpilih dari mikroorganisme utamanya yang bersifat fermentasi, yaitu bakteri asam laktat (Lactobacillus, sp.), Jamur fermentas (Saccharomyces, sp), bakteri fotosintetik (Rhodopseudomonas, sp.), dan Actinomycetes (Higa et al., 1995). Bakteri asam laktat (Lactobacillus, sp.) yang terdapat didalam EM4 bakteri ini dapat menekan pertumbuhan mikroorganisme yang merugikan; meningkatkan percepatan perombakan bahan organik; menghancurkan bahan organik seperti lignin dan selulosa serta memfermentasikannya tanpa menimbulkan senyawa beracun yang ditimbulkan dari pembusukan bahan organik.

Limbah pertanian dan peternakan yang dikomposkan memberi peluang kepada peternak sapi potong untuk memperoleh tambahan penghasilan, juga masalah pencemaran lingkungan petani dari limbah buangan kulit kopi dapat terpecahkan. Hasil penelitian pembuatan kompos dengan menggunakan aktivator MOL bongkol pisang dan agrisimba oleh Farida et al. (2013) dengan kondisi pengomposan 30 hari dan penggunaan MOL bonggol pisang sebanyak $25 \mathrm{ml}, 27 \mathrm{ml}$, dan $30 \mathrm{ml} / 5 \mathrm{~kg}$ bahan terdiri dari blotong 3 $\mathrm{kg}$ dan kulit kopi $2 \mathrm{~kg}$ memberikan hasil ratarata terbaik pada penambahan MOL bonggol pisang sebesar $30 \mathrm{ml}$.

Berdasarkan pemanfaatan limbah peternakan dan pertanian tersebut, maka perlu dilakukan penelitian pengaruh penambahan berbagai imbangan aktivator MOL bongkol pisang dan EM4 pada pengomposan feses sapi potong dan kulit kopi terhadap kualitas Fisik kompos dengan tujuan mengetahui Kompisisi yang terbaik dari aktivator MOL bongkol pisang dan EM4 hasil pengomposan.

\section{METODE}

\section{Tempat dan waktu}

Penelitian ini telah dilaksanakan dikebun percobaan dan rumah kompos Fakultas Pertanian Prodi Peternakan Universitas Musi Rawas serta Analisa kimia tanah di lakukan di Laboratorium Fakultas Pertanian Jurusan Ilmu Tanah Universitas Sriwijaya. Pelaksanan penelitian dilakukan selama bulan April sampai dengan bulan Juni 2015.

\section{Bahan dan Alat}

Bahan yang digunakan pada penelitian ini adalah feses sapi potong, kulit kopi, MOL bonggol pisang, dan EM4 diberikan sesuai dengan taraf perlakuan yaitu $25 \mathrm{ml}, 30 \mathrm{ml}$, dan $35 \mathrm{ml}$.

Alat yang digunakan dalam penelitian ini adalah: kantung plastik ukuran $10 \mathrm{~kg}$ sebanyak 24 buah, pisau besar, meteran, tali, dan label plastik, selang, jerigen, sprayer, dan ember, timbangan digital dan analog, sekop dan cangkul, termometer, spidol, dan $\mathrm{pH}$ meter. Penelitian ini menggunakan metode eksperimental dengan Rancangan Acak Lengkap (RAL) yang terdiri dari 6 perlakuan $\mathrm{A} 1=25 \mathrm{ml}$ MOL bonggol pisang, $\mathrm{A} 2=30$ $\mathrm{ml}$ MOL bonggol pisang, $\mathrm{A} 3=35 \mathrm{ml} \mathrm{MOL}$ bonggol pisang, $\mathrm{A} 4=25 \mathrm{ml} \mathrm{EM} 4, \mathrm{~A} 5=30 \mathrm{ml}$ EM4, dan A6 = $35 \mathrm{ml} \mathrm{EM4,} \mathrm{semua} \mathrm{perlakuan}$ menggunakan feses sapi potong sebanyak $3 \mathrm{~kg}$ dan kulit kopi $2 \mathrm{~kg}$ sehingga total berat bahan kompos $5 \mathrm{~kg}$. Masing-masing perlakuan di ulang sebanyak 4 kali sehingga di peroleh 24 unit percobaan.

\section{Prosedur Penelitian}

EM4 diperoleh ditoko pertanian sedangkan MOL bongkol pisang dibuat sendiri dengan prosedur:

\section{Tahap pertama: Pembuatan MOL}

Penelitian ini diawali dengan persiapan pembuatan media biakan MOL bongkol pisang. Bahan berupa $1 \mathrm{~kg}$ bongkol pisang, $0,25 \mathrm{~kg}$ gula merah, dan 2 liter air cucian beras dipersiapkan terlebih dahulu. Tahapan 
pembuatannya adalah: 1) Bongkol pisang diiris tipis-tipis kemudian ditumbuk, 2) Gula merah diiris tipis-tipis untuk mempermudah dilarutkan dengan air cucian beras, 3) Bongkol pisang, gula merah dan air cucian beras dimasukan kedalam ember kemudian diaduk hingga merata, dan 4) Semua bahan yang telah dicampur didalam ember kemudian dimasukkan ke dalam jerigen 5 liter, pada bagian tutupnya diberi lubang dan selang kecil yang dihubungkan dengan botol air mineral bekas untuk mengeluarkan sisa-sisa gas hasil fasil fermentasi kemudian difermentasi selama 15 hari.

\section{Tahap kedua: Pembuatan Kompos.}

Proses pembuatan kompos dilakukan dengan mencampur dua bahan yang terdiri dari feses sapi potong dan kulit kopi. Feses sapi potong sebanyak 3 kilogram dan kulit kopi 2 kilogram kemudian ditimbang. Kemudian diberi larutan MOL dan EM4 sesuai perlakuan dan dilakukan pengadukan, setelah merata, dimasukan kedalam kantung plastik dengan ukuran 10 kilogram, dilakukan pengukuran suhu awal dan $\mathrm{pH}$ awal kompos kemudian disimpan secara anaerobik selama 30 hari. Bahan kompos yang telah diinkubasi selama 30 hari dan telah matang, selanjutnya diambil sampel sebanyak 200 gram dan dilakukan uji fisik untuk mengetahui suhu, $\mathrm{pH}, \mathrm{Bau} / \mathrm{aroma}$, warna, dan tekstur.

\section{Tahap ketiga: Uji Fisik}

Uji fisik yang diamati terdiri dari suhu, $\mathrm{pH}$, bau/aroma, warna dan tekstur dari kompos hasil penelitian. Pada uji fisik ini diambil setiap sampel kompos sebanyak 200 gram diletakkan pada alas piring plastik lalu diletakkan diatas meja diamati bentuk fisik kompos dengan mengunakan panalis sebanyak 10 orang. Pengamatan suhu dan $\mathrm{pH}$ dilakukan pada awal dan akhir proses pengomposan. Adapun tahapan uji fisik yang dilakukan adalah: 1) Pada pengukuran suhu kompos dilakukan dengan thermometer digital dengan cara menacapkan thermometer kedalam kompos dan dicatat hasilnya, 2) Pengukuran $\mathrm{pH}$ mengacu pada prosedur Naumann dan Bassler (1997), dengan mengunakan $\mathrm{pH}$ digital, kompos ditimbang 10 gram dan ditambahkan aquades $100 \mathrm{ml}$ diendapkan selama 15 menit kemudian $\mathrm{pH}$ diukur dan dicatat, dan 3) Untuk uji warna, bau dan tekstur data yang diperoleh dilakukan uji Kruskal Wallis secara organoleptik yang meliputi warna, bau, dan tekstur dengan skala numerik sebagai berikut: Warna, dengan skala nilai: $1=$ hijau pucat, $2=$ hijau pekat, 3 = coklat, $4=$ coklat kehitaman, $5=$ hitam tanah. Bau, dengan skala nilai: 1 = berbau busuk, 2 = tidak berbau tanah, 3 = agak berbau tanah, 4 = berbau tanah, 5 = sangat berbau tanah. Tekstur, dengan skala nilai: $1=$ sangat kasar, $2=$ kasar, 3 $=$ agak halus, $4=$ halus, $5=$ sangat halus (Kastalani, 2014).

\section{HASIL DAN PEMBAHASAN}

\section{Suhu Kompos}

Salah satu parameter pada pengomposan yang menunjukkan ukuran panas dan dinginnya suatu benda adalah suhu atau temperatur. Pengukuran suhu dilakukan pada awal dan akhir proses pengomposan. Tingkat panas dingin yang terjadi pada kompos disebabkan oleh aktivitas mikroorganisme bahan pengomposan.

Hasil analisis ragam, penambahan aktivator dalam feses sapi potong dan kulit kopi menunjukkan berpengaruh tidak nyata $(\mathrm{P}>0,05)$ (Tabel 1). Suhu pengomposan feses sapi potong dan kulit kopi dengan aktivator rata-rata adalah $30,80^{\circ} \mathrm{C}$ (Tabel 2 ).

Pengaruh yang tidak nyata pada suhu pengomposan. Hal ini dikarenakan proses pengompos dilakukan secara anaerob atau tertutup. Proses anaerob akan menghasilkan energi/panas yang jauh lebih kecil. Semakin sedikit energi artinya 
Tabel 1. Kualitas Fisik Kompos Feses Sapi Potong dan Kulit Kopi dengan Penambahan Aktivator MOL Bongkol Pisang dan Kulit Kopi

\begin{tabular}{clcc}
\hline No & Parameter & Perlakuan A & KK (\%) \\
\hline 1. & Suhu & $0,88^{\text {tn }}$ & $0,67 \%$ \\
2. & pH & $1,71^{\text {tn }}$ & $3,49 \%$ \\
3. & Bau/Aroma & $1,48^{\text {th }}$ & $13,64 \%$ \\
4. & Warna & $2,59^{\text {tn }}$ & $12,30 \%$ \\
5. & Tekstur & $4,15^{*}$ & $11,94 \%$ \\
\hline
\end{tabular}

Keterangan: $\mathrm{A}=$ Aktivator, $\mathrm{KK}=$ Koefisien Keragaman, $\mathrm{tn}=$ Berpengaruh Tidak Nyata, $*=$ Berpengaruh Nyata

Tabel 2. Nilai Parameter Pengamatan Kualitas Fisik Kompos Feses Sapi Potong dan Kulit Kopi dengan Penambahan Aktivator MOL Bongkol Pisang dan Kulit Kopi

\begin{tabular}{|l|c|c|c|c|c|c|c|c|}
\hline \multirow{2}{*}{ Parameter } & \multicolumn{7}{|c|}{ Perlakuan } & \multicolumn{2}{c|}{ SNI } \\
\cline { 2 - 9 } & A1 & A2 & A3 & A4 & A5 & A6 & Min & Mak \\
\hline Suhu $\left({ }^{\circ} \mathrm{C}\right)$ & $30,76 \pm 0,05$ & $30,94 \pm 0,38$ & $30,68 \pm 0,12$ & $30,83 \pm 0,17$ & $30,73 \pm 0,06$ & $30,86 \pm 0,25$ & $\pm 30^{\circ} \mathrm{C}$ & - \\
\hline $\mathrm{pH}$ & $6,29 \pm 0,35$ & $6,06 \pm 0,15$ & $6,25 \pm 0,24$ & $5,93 \pm 0,12$ & $6,01 \pm 0,11$ & $6,10 \pm 0,22$ & 6,80 & 7,49 \\
\hline Bau & $1,93 \pm 0,38$ & $2,20 \pm 0,27$ & $2,33 \pm 0,22$ & $1,90 \pm 0,35$ & $2,20 \pm 0,26$ & $2,25 \pm 0,24$ & 3,00 & - \\
\hline Warna & $1,75 \pm 0,06$ & $1,75 \pm 0,26$ & $2,18 \pm 0,24$ & $1,73 \pm 0,29$ & $1,90 \pm 0,22$ & $1,70 \pm 0,22$ & 2,00 & - \\
\hline Tekstur & $1,55^{\mathrm{a}} \pm 0,21$ & $1,60^{\mathrm{a}} \pm 0,22$ & $1,70^{\mathrm{b}} \pm 0,23$ & $1,70^{\mathrm{b}} \pm 0,32$ & $1,90^{\mathrm{c}} \pm 0,14$ & $2,13 \mathrm{~d} \pm 0,95$ & 2,00 & - \\
\hline
\end{tabular}

Keterangan: Angka-angka yang diikuti oleh huruf yang berbeda pada baris yang sama berarti berbeda tidak nyata pada taraf uji BNJ 5\% dan 1\%, bau 3 (berbau tanah), warna 2 (coklat kehitaman), tekstur 2 (agak halus)

panas yang dihasilkan semakin kecil dan berpengaruh pada rendahnya temperatur kompos. Hal ini sesuai dengan pendapat Wahyono dan Sahwan (2008), menyatakan ketersediaan oksigen mempengaruhi aktivitas mikrobiologi, semakin tinggi laju penyerapan oksigen semakin tinggi suhunya. Semakin rendah penyerapan oksigen maka akan semakin rendah juga suhu yang dihasilkan. Pengomposan secara anaerob temperatur yang dicapai adalah temperatur mesofilik $\left(15^{\circ} \mathrm{C}\right.$ - $35^{\circ} \mathrm{C}$ ). Menurut Braun (2007) sebagian besar pengomposan anaerob terjadi pada temperatur mesofilik $\left(30-35^{\circ} \mathrm{C}\right)$. Pembuatan kompos cara anaerob ialah modofikasi bilogis pada struktur kimia dan biologi bahan organik tanpa bantuan udara atau oksigen sedikitpun (hampa udara). Sumekto (2006) dalam Turangga et al. (2014) menyatakan bahwa pembuatan kompos cara anaerob merupakan metode biologis tanpa bantuan udara (anaerob) dan merupakan proses yang dingin dan menyebabkan tidak terjadinya fluktuasi suhu/temperatur.

\section{pH Kompos}

Derajat keasaman atau $\mathrm{pH}$ pada proses dekomposisi bahan yang akan dikomposkan merupakan faktor penting dalam proses pengomposan. Terjadinya perubahan $\mathrm{pH}$ menunjukkan adanya aktivitas mikroorganisme dalam mendegradasi bahan organik. Rataan $\mathrm{pH}$ kompos dapat dilihat pada Tabel nilai parameter pengamatan kualitas fisik kompos feses sapi potong dan kulit kopi dengan penambahan aktivator Mol bonggol pisang dan EM4. Hasil analisis sidik ragam penambahan aktivator feses sapi potong dan kulit kopi menunjukkan berpengaruh tidak nyata $(\mathrm{P}>0,05)$ (Tabel 1). Hal ini dimenunjukkan penambahan aktivator Mol bonggol pisang dan EM4 memberikan pengaruh yang sama baik terhadap $\mathrm{pH}$ kompos feses sapi potong dan kulit kopi yang 
dihasilkan yaitu $\mathrm{pH}$ optimal bagi mikroba untuk mendekomposisi bahan yang akan dikomposkan.

Derajat keasaman merupakan salah satu faktor yang mempengaruhi kehidupan mikroorganisme di dalam tanah, sehingga mempengaruhi kesuburan tanaman. Hasil analisis menunjukkan bahwa $\mathrm{pH}$ kompos secara umum telah memenuhi standar SNI yaitu 6,8 - 7,3. Proses dekomposisi kompos dapat bekerja dengan baik pada rentang $\mathrm{pH}$ optimal. Xueling (2006) dalam Kusuma (2012), pH optimal bagi bakteri yang bekerja dalam dekomposisi kompos terletak antara 6,0 dan 7,5. Sedangkan $\mathrm{pH}$ optimal bagi fungi dalam proses pengomposan terletak antara 5,5 dan 8,5 . Pada penelitian ini rentang $\mathrm{pH}$ antara 5,93 dan 6,29 (Tabel 2). Kondisi pH ini tidak bermasalah pada laju proses dekomposisi kompos karena sesuai dengan $\mathrm{pH}$ optimal untuk pengomposan.

Nilai $\mathrm{pH}$ kompos yang mendekati netral juga menunjukkan bahwa kompos sudah matang. $\mathrm{pH}$ netral disebabkan karena aktivitas mikroba mulai menurun karena sedikitnya zat-zat yang dapat dirombak sehingga menyebabkan pembentukan kationkation basa pada proses mineralisasi menjadi berkurang. Nilai pH kompos yang berbeda tidak nyata menunjukkan mikroba MOL bongkol pisang dan EM4 dapat merombak bahan dengan efektifitas yang sama.

\section{Bau/Aroma Kompos}

Hasil observasi terhadap bau/aroma kompos tertera pada Tabel nilai parameter pengamatan kualitas fisik kompos feses sapi potong dan kulit kopi dengan penambahan aktivator Mol bongkol pisang dan EM4. Hasil analisis ragam penambahan aktivator dalam feses sapi potong dan kulit kopi menunjukkan berpengaruh tidak nyata $(\mathrm{P}>0,05)$ (Tabel 1). Hal ini diduga bahwa hasil pengomposan dengan mengunakan aktivator MOL bongkol pisang dan EM4 menghasilkan bau/aroma yang sama baik yaitu sama-sama mendekati bauatau aroma tanah. Yuwono (2005), menyatakan bahwa pupuk yang telah matang akan berbau seperti humus atau tanah, bila kompos berbau busuk menandakan bahwa proses dekomposisi belum selesai dan proses penguraian masih berlangsung.

Hasil analisa ragam menunjukkan berpengaruh tidak nyata $(\mathrm{P}>0,05)$ terhadap bau/aroma pengomposan artinya penambahan aktivator MOL bongkol pisang dan EM4 sama-sama memiliki bau/aroma yang mendekati dengan standar SNI 19-7030-2004, hal ini menunjukkan kompos yang dihasilkan tidak ada yang berbau busuk. Menurut Isroi (2009), bila tercium bau yang tidak sedap berarti kompos belum matang, sebaliknya pupuk yang telah matang akan berbau seperti tanah. Cahaya dan Nugraha (2008) dalam Ismayana et al. (2012) menambahkan kompos yang telah matang berbau seperti tanah, karena materi yang dikandungnya sudah menyerupai materi tanah dan berwarna coklat kehitam-hitaman yang terbentuk akibat pengaruh bahan organik yang sudah stabil. Bentuk akhir sudah tidak menyerupai bentuk aslinya karena sudah hancur akibat penguraian alami oleh mikroorganisme yang hidup di dalam kompos. Selanjutnya Djuarnani dan Setiawan, (2005) menyatakan pupuk/kompos yang berbau busuk menandakan bahwa proses dekomposisi belum selesai dan proses penguraian masih berlangsung sebaliknya bila pupuk/kompos telah matang akan berbau seperti humus atau tanah.

\section{Warna Kompos}

Hasil observasi terhadap bau/aroma kompos tertera pada Table 2. Hasil analisis sidik ragam penambahan aktivator dalam feses sapi potong dan kulit kopi menunjukakan berpengaruh tidak nyata $(\mathrm{P}>0,05)$ (Tabel 1). Hal ini menunjukkan bahwa kompos yang dihasilkan memberikan warna yang sama baik. Berdasarkan uji fisik warna dengan beberapa responden, rata-rata seluruh kompos sesuai dengan standar SNI 19-7030-2004. Berdasarkan parameter pengamatan warna seluruh kompos termasuk kedalam kategori cokelat kehitaman seperti warna tanah. Hal ini sesuai dengan pendapat Djuarnani dan Setiawan (2005) bahwa warna kompos yang 
telah matang lebih menyerupai warna tanah.

Warna pada kompos hasil penelitian sudah memenuhi SNI kompos yaitu 2 (coklat kehitaman) (Tabel 2), dalam penelitian ini hampir semua menyerupai warna tanah yaitu coklat kehitaman artinya warna kompos dengan penambahan aktivator semua hasil penelitian ini sudah menyerupai materi tanah dan berwarna coklat kehitam-hitaman akibat pengaruh bahan organik yang sudah stabil, serta dipengeruhi oleh bahan pembuat kompos yaitu feses sapi potong dan kulit kopi. Sutanto (2002), menyatakan bahwa kompos yang telah matang memiliki sifat fisik sama seperti tanah dan humus yaitu kehitaman dan remah serta proses dekomposisi oleh mikroba pada pengomposan berjalan dengan baik. Warna coklat kehitaman pada hasil pengomposan juga dipengaruhi oleh adanya aktivator yang ditambahkan sehingga mempercepat proses pengomposan. Hal ini sesuai dengan pendapat Widawati (2005) menyatakan bahwa warna hasil pengomposan dipengaruhi oleh bahan tambahan berupa aktivator yang diberikan pada proses pengomposan sehingga proses pematangan kompos dipercepat oleh mikroba tersebut.

\section{Tekstur Kompos}

Hasil pengamatan terhadap tekstur kompos tertera pada Table nilai parameter pengamatan kualitas fisik kompos feses sapi potong dan kulit kopi dengan penambahan aktivator Mol bongkol pisang dan EM4. Hasil analisis sidik ragam penambahan aktivator dalam feses sapi potong dan kulit kopi menunjukakan berpengaruh nyata $(\mathrm{P}<0,05)$ terhadap tekstur kompos (Tabel 1). Dari tabel terlihat bahwa rata-rata tekstur terendah pada perlakuan A1 $(1,55)$ dan diikuti dengan perlakuan A2 (1,60), A3 dan A4 (1,70), A5 $(1,90)$ serta rata-rata tertinggi pada perlakuan A6 (2,13) (Tabel 2). Berdasarkan uji fisik tekstur kompos dengan beberapa responden, rata-rata seluruh kompos sesuai dengan standar SNI 19-7030-2004. Berdasarkan parameter pengamatan tekstur seluruh kompos termasuk kedalam kategori agak halus.
Hasil analisis ragam penambahan aktivator dalam feses sapi potong dan kulit kopi menunjukkan berpengaruh nyata terhadap tekstur kompos dan tekstur pada kompos hasil penelitian sudah memenuhi SNI kompos yaitu 2 (agak halus). Hal ini diduga karena susunan bahan pembuatan kompos yang digunakan hanya terdiri dari kotoran sapi dan kulit kopi, dimana kulit kopi sendiri teksturnya cenderung agak halus sehingga ketika dijadikan sebagai bahan penyusun pembuatan kompos maka akan menghasilkan pupuk kompos dengan tekstur yang agak halus. Hal ini sesuai dengan pendapat Budi (2015) Faktor yang mempengaruhi proses pengomposan adalah rasio $\mathrm{C} / \mathrm{N}$, ukuran partikel, aerasi, porositas, kelembaban (moisture content), temperatur, derajat keasaman $(\mathrm{pH})$, dan kandungan hara. Selanjutnya Murbandono (2002), menyatakan agar pembuatan pupuk organik dapat berhasil maka diperlu diperhatikan susunan bahan yang akan dibuat kompos atau bahan dasarnya, dimana semakin kecil ukuran partikel bahan kompos maka akan semakin cepat pula proses pematangannya, karena semakin banyak permukaan yang tersedia untuk bakteri pembusuk untuk menghancurkan material tersebut. Menurut Sutanto (2002), aktivitas mikroba berada diantara permukaan area dan udara. Permukaan area yang lebih luas akan meningkatkan kontak antara mikroba dengan bahan dan proses dekomposisi akan berjalan lebih cepat. Ukuran partikel juga menentukan besarnya ruang antar bahan (porositas). Untuk meningkatkan luas permukaan dan mempercepat proses dekomposisi bahan dapat dilakukan dengan memperkecil ukuran partikel bahan tersebut dengan cara dicacah atau dipotong-potong.

\section{KESIMPULAN}

Kualitas kompos hasil penelitian telah memenuhi Standar Nasional Indonesia (SNI) pupuk organik No. 19-7030-2004. Hasil penelitian dapat disimpulkan bahwa kualitas fisik kompos feses sapi potong dan kulit kopi 
dengan penambahan aktivator mol bonggol pisang dan EM4 memberikan hasil tekstur yang terbaik pada perlakuan A6 $(2,13)$ yaitu penambahan aktivator $35 \mathrm{ml}$ EM4 pada 5 kg bahan kompos (feses + kulit kopi) dan hasil penambahan kedua jenis aktivator yaitu Mol Bongkol pisang dan EM4 memberikan pengaruh yang sama baik terhadap kualitas fisik seperti suhu, $\mathrm{pH}$, bau/aroma dan warna kompos yang dihasilkan.

\section{DAFTAR PUSTAKA}

Baon, J. B., R. Sukasih, dan Nurkholis. 2005. Laju dekomposisi dan kualitas kompos limbah padat kopi: pengaruh aktivator dan bahan baku kompos. Pelita Perkebunan, 21 : 31-42.

Braun, R. 2007. Anaerobic Digestion: A Multi-Faceted Process For Energy, Environmental Management and Rural Development. Dalam Improvement of Crop Plants for Industrial End Uses. Editor P. Ranalli. Springer Netherlands.

Biro Pusat Statistik. 2011. Rilis hasil akhir pendataan sapi potong, sapi perah dan kerbau 2011. Kementrian Pertanian. Jakarta.

Biro Pusat Statistik Sumatera Selatan. 2014. Sumatera Selatan dalam angka 2013. BPS Provinsi Sumatera Selatan dan BAPPEDA Provinsi Sumatera Selatan.

Budi, N. W. 2015. Pengaruh Rasio C/N Bahan Baku Pada Pembuatan Kompos Dari Kubis Dan Kulit Pisang, Jurnal Integrasi Proses Vol. 5, No. 2, 77.

Farida, A., Sumiyati, S. dan Handayani, D. S. 2013. Studi perbandingan pengaruh penambahan aktivator agri simba dengan mol bongkol pisang terhadap kandungan unsur hara makro (cpnk) kompos dari blotong (sugarcane filter cake) dengan variasi penambahan kulit kopi. Jurnal teknik lingkungan 3 (1) : $1-11$.

Higa, T and J. F. Parr. 1995. Beneficial and Effective Microorganisms for a Sustainable Agriculture and Environtment. Soil Microbiologist Agricultural Research Service, US. Department of Agriculture Beltsville. Maryland.

Isroi. 2009. Pupuk Organik Granul, Sebuah Petunjuk Paraktis, Peneliti pada Balai Penelitian Bioteknologi Perkebunan Indonesia, Bogor.

Ismayana, A., Nastiti, S. I., Suprihatin., Maddu, A. dan Fredy. A. 2012. Faktor rasio $\mathrm{C} / \mathrm{N}$ awal dan laju aerasi pada proses Co-Composting Bagasse dan blotong. Jurnal Teknologi Industri Pertanian. 22 (3):173-179.

Djuarnani, N. dan B Setiawan. 2005. Cara cepat membuat kompos. Agro Media Pustaka. Jakarta.

Kusuma, M. A. 2012. Pengaruh Variasi Kadar Air Terhadap Laju Dekomposisi Kompos Sampah Organik kota Depok. Tesis, Universitas Indonesia.

Kastalani. 2014. Pengaruh Tingkat konsentrasi dan lamanya Inkubasi EM4 terhadap kualitas Organoleptik pupuk Bokashi. Jurnal Ilmu tropika 3 (2) : $10-14$.

Murbandono, H. S. L. 2002. Membuat Kompos. Penerbit Penebar Swadaya. Jakarta.

Menteri Pertanian. 2010. Peraturan Menteri Pertanian No: 70/Permentan/SR.140/1 0/2011. Tentang pupuk organik.

Moses, B. B. O., A. Wibowo., Jati. B., B. Rahardjo Si. 2013. Penggunaan Mikroorganisme Bongkol Pisang (Musa paradisiaca) Sebagai Dekomposer Sampah Organik. Jurnal Teknobiologi Universitas AtmaJaya Yogyakarta .Vol (2): $7-10$

Naumann, C. and R. Bassler. 1997. VCLUFAMethodenbuch Band III, Die chemische Untersuchung von Futtermitteln. $3^{\text {nd }}$. Darmstadt, Germany.

Rifa'i, A. Mien. 2004. Kamus biologi. Cetakan ke-4. Balai Pustaka Jakarta. 
Halaman 11.

Standar Nasional Indonesia (SNI). 2010. Pupuk NPK padat. Standar Nasional Indonesia. Jakarta.

Sutanto R. 2002. Pertanian Organik, Menuju Pertanian Alternatif dan Berkelanjutan. Penerbit Kanisius. Yogyakarta.

Turangga B. S. G., Bambang, D. A. dan Musthofa. L. 2014. Pemanfaatan limbah nangka (Artocarpus heterophyllus) pada proses pengomposan anaerob dengan menambahkan variasi konsentrasi EM4 (Effective Microorganisme) dan variasi bobot bulking agent. Jurnal Keteknikan Pertanian Tropis dan Biosistem 3 (2) : 141-147.

Wahyono, S. dan F. L. Sahwan. 2008. Dinamika Perubahan Temperatur dan
Reduksi Volume Limbah Dalam Proses Pengomposan. Jurnal Tekenologi. Lingkungan 9 (3): 255-262. Issn 1441318x.

Widawati S. 2005. Daya pacu aktivator fungi asal kebun biologi wamena terhadap kematangan hara kompos, serta jumlah mikroba pelarut fosfat dan penambat nitrogen.Jurnal Biodiversitas.V (6).4: 238-241.

Yuwono, D. 2005. Kompos. Penebar Swadaya. Jakarta.

Yuli, A. H., Eulis. T. M., Tb. Benito, A. K. dan Ellin. H. 2010. Pengaruh Campuran Feses Sapi Potong dan Feses Kuda Pada Proses Pengomposan Terhadap Kualitas Kompos. Jurnal Ilmu-ilmu Peternakan 8 ( 6 ) : 299-303. 